\title{
PENGARUH IMPLEMENTASI TOTAL QUALITY MANAGEMENT TERHADAP KEPUASAN PELANGGAN PADA PERUSAHAAN BARJAZ DI DENPASAR
}

\author{
Pebriani Efendi ${ }^{1}$ \\ Kastawan Mandala ${ }^{2}$ \\ ${ }^{1,2}$ Fakultas Ekonomi dan Bisnis Universitas Udayana (Unud), Bali - Indonesia \\ email:pebrianiefendi@gmail.com
}

\begin{abstract}
ABSTRAK
Kepuasan pelanggan merupakan hal yang perlu diperhatikan karena menyangkut perasaan senang atau kecewa yang muncul dari pelanggan setelah membandingkan antara persepsi hasil kinerja perusahaan dan harapan-harapannya. Agar pelanggan merasa puas, suatu perusahaan perlu memperhatikan faktor-faktor yang mempengaruhi kepuasan pelanggan seperti menerapkan Total Quality Management. Tujuan penelitian ini adalah untuk mengetahui apakah variabel Total Quality Management yang terdiri dari fokus pada pelanggan, obsesi pada kualitas dan kerjasama tim mempunyai pengaruh terhadap kepuasan pelanggan. Penelitian ini dilakukan di Barjaz. Pengumpulan data dilakukan melalui penyebaran kuesioner dan wawancara. Teknik analisis data yang digunakan adalah regresi linier berganda. Berdasarkan hasil analisis ditemukan bahwa variabel fokus pada pelanggan, obsesi pada kualitas, dan kerjasama tim secara simultan berpengaruh signifikan terhadap kepuasan pelanggan. Nilai koefisien determinasi sebesar 0.583 menunjukkan bahwa 58,3 persen variasi kepuasan pelanggan bisa dijelaskan oleh ketiga variabel independen yang digunakan dalam persamaan regresi, sedangkan sisasnya sebesar 41,7 persen dijelaskan oleh variabel lain diluar ketiga variabel yang digunakan dalam penelitian ini.
\end{abstract}

Kata Kunci: kepuasan pelanggan, manajemen operasi, total quality management

\begin{abstract}
Customer satisfaction is a matter of concern because it involves feelings of pleasure or disappointment that arise from the customer after comparing the perceptions of company performance results and expectations. In order for customers to be satisfied, a company needs to pay attention to the factors that affect customer satisfaction such as applying Total Quality Management. The purpose of this study is to determine whether the variable Total Quality Management consisting of focus on the customer, obsession on quality and teamwork have an influence on customer satisfaction. This study was conducted in Barjaz. Data collection was done through questionnaires and interviews. Data analysis technique used is multiple linear regression. Based on the results of the analysis found that the variable focus on the customer, obsession on quality, and teamwork simultaneously significant effect on customer satisfaction. Determination coefficient value of 0.583 indicates that 58.3 percent of customer satisfaction variation can be explained by the three independent variables used in the regression equation, while the sisasnya 41.7 percent explained by other variables outside the three variables used in this study.
\end{abstract}

Keywords : customer satisfaction, operations management, total quality management 


\section{PENDAHULUAN}

Indonesia merupakan negara dengan jumlah penduduk yang sangat padat, banyak industri yang dapat berkembang. Industri yang selalu dibutuhkan oleh pelanggan adalah makanan dan minuman. Fokus terhadap industri minuman, banyak berbagai macam minuman yang dikembangkan seperti air mineral, minuman isotonik dan minuman teh. Minuman teh yang banyak dikembangkan akhir-akhir ini adalah teh Thailand, teh Thailand adalah minuman berbahan dasar teh khas Thailand yang dicampur dengan susu, gula dan susu kental manis. Thai tea diguyuri susu evaporated, santan atau susu full cream yang memberi tekstur. Salah satu usaha yang menjual Thai tea adalah Barjaz.

Perusahaan Barjaz didirikan tahun 2012 oleh Arriansetiagama. Barjaz memiliki beberapa cabang yang terdiri dari 10 cabang diseluruh kota Denpasar, namun Barjaz yang paling besar berada di Jalan Diponegoro No 173, Denpasar. Awal berdirinya Barjaz hanya memiliki dua varian rasa yaitu teh Thailand original dan greentea. Seriring berjalannya waktu dan Perusahaan Barjaz semakin berkembang, kini Barjaz memiliki penambahan rasa yaitu rasa pisang, taro, coklat dan strawberry. Harga yang ditawarkan Barjaz lebih murah dari para pesaing lainnya, teh Thailand milik Barjaz dijual seharga Rp. 15.000 sedangkan teh Thailand milik pesaing di jual dengan harga Rp 18.000 sampai Rp. 22.000. Harga yang lebih murah diharapkan dapat menjangkau seluruh kalangan masyarakat, jadi teh Thailand milik Barjaz dapat dirasakan oleh seluruh lapisan masyarakat.

Banyaknya bermunculan jenis usaha yang sama membuat Perusahaan Barjaz harus lebih meningkatkan kualitas produk dan pelayanannya dengan cara 
mengevaluasi secara berkala kinerja dari perusahaannya. Namun, Management Barjaz belum mengevaluasi secara keseluruhan sistem manajemennya, membuat perusahaannya kurang maksimal dalam memproduksi produk teh Thailand sehingga kualitas yang dihasilkan juga kurang maksimal. Hal tersebut menimbulkan dampak terhadap kepuasan pelanggan perusahaan Barjaz. Solusi yang muncul untuk menghadapi persaingan yang semakin tajam adalah Total Quality Management. Total Quality Management adalah sistem untuk mengukur seluruh total kualitas yang harus diperhatikan dalam suatu perusahaan seperti organisasi, proses dan lingkungannya.

Beberapa peneliti terdahulu telah melakukan penelitian yang berhubungan dengan pengaruh Total Quality Management terhadap kepuasan pelanggan diantaranya Kurniawati (2011), Jaafreh (2013) ,Elvirawati (2013), Mahami (2015), Sukardi (2016) yang menunjukkan bahwa variabel (fokus pada pelanggan, obsesi terhadap kualitas dan kerjasama tim) berpengaruh secara positif signifikan terhadap kepuasan pelanggan. Namun penelitian Citraluki (2016), Rahman (2011), dan Mosahab (2013) menunjukkan bahwa obsesi kualitas tidak memiliki dampak yang signifikan pada kepuasan pelanggan.

Tujuan dari penelitian ini adalah untuk menjelaskan pengaruh fokus pada pelanggan terhadap kepuasan pelanggan perusahaan Barjaz, untuk menjelaskan pengaruh obsesi terhadap kualitas terhadap kepuasan pelanggan perusahaan Barjaz, dan untuk menjelaskan pengaruh kerjasama tim terhadap kepuasan pelanggan perusahaan Barjaz. 
Penelitian ini dapat memberikan dua kegunaan yaitu teoritis dan praktis. Kegunaan teoritis dapat memberikan tambahan referensi, informasi dan wawasan untuk penelitian selanjutnya yang berhubungan dengan pelaksanaan Total Quality Management yang dilaksanakan perusahaan. Kegunaan praktis dapat memberikan tambahan pengetahuan dan pemahaman mahasiswa mengenai pengaplikasian teori yang telah diperoleh selama menempuh pendidikan di perguruan tinggi terutama yang berkaitan dengan Total Quality Management. Bagi Perusahaan, hasil yang diperoleh dari penelitian ini dapat dijadikan alternatif untuk melaksanakan Total Quality Management yang efektif.

\section{TELAAH LITERATUR DAN PENGEMBANGAN HIPOTESIS}

\section{Kualitas}

Kualitas adalah tingkat baik buruknya sesuatu (Jaafreh, 2013). Istilah kualitas banyak dipergunakan dalam dunia bisnis rekayasa, dan manufaktur dalam kaitannya dengan teknik dan konsep untuk memperbaiki kualitas produk atau jasa yang dihasilkan, seperti Six Sigma, Total Quality Management, Kaizen, dll. Tujuan dari seluruh organisasi bisnis atau jasa adalah membuat atau memproduksi barang dan jasa yang berkualitas sehingga akan menimbulkan perasaan puas di benak konsumen (Qamari, 2011)Kualitas terdiri dari kualitas produk dan kualitas pelayanan. Kualitas produk memiliki 8 dimensi yaitu performa, features, keandalan, konformitas, daya tahan, kemampuan pelayanan, kualitas yang dipersepsikan dan estetika (Nasution, 2001:17-18).. Kualitas layanan memiliki 5 dimensi yaitu bukti langsung, kehandalan, daya tanggap, jaminan dan empati (Tjiptono, 2003:70). 


\section{Total Quality Management (TQM)}

Total Quality Management ialah sistem manajemen dengan melibatkan seluruh atau total anggota organisasi untuk meningkatkan total kualitas menuju kesuksesan bersaing yang bertujuan untuk membuat pelanggan puas (Yamit, 2004: 181). Total Quality Management merupakan suatu ilmu yang dilaksanakan secara berkesinambungan melalui proses manajemen yang melibatkan semua elemen termasuk karyawan untuk mencapai kualitas yang maksimal (Prawirosentono, 2001:17). Total Quality Management merupakan suatu pendekatan dalam menjalankan bisnis yang menggunakan seluruh elemen yang ada di dalam perusahaan termasuk produk, jasa, proses, manusia, dan lingkungannya yang berusaha memaksimalkan daya saing organisasi supaya dapat bertahan dengan para pesaing ( Siswanto, 2006 :195). Manfaat dari penerapan Total Quality Management adalah untuk memperbaiki keseluruhan kualitas yang ada di dalam perusahaan agar dapat meningkatkan penghasilan atau profit dari perusahaan. Perbaikan kualitas yang secara terus menurus akan memperbaiki kinerja perusahaan dan membuat citra baik perusahaan sehingga akan menimbulkan kepuasan pelanggan.

\section{Kepuasan Pelanggan}

Kepuasan pelanggan telah menjadi konsep sentral dalam teori dan praktik pemasaran, serta merupakan salah satu tujuan esensial bagi aktivitas bisnis. Pada hakikatnya tujuan bisnis adalah untuk menciptakan dan mempertahankan para pelanggan (Andre, 2014). Terbentuknya kepuasan pelanggan bisa menghasilkan beberapa manfaat, yaitu keharmonisan antara perusahaan dan pelanggannya, 
terciptanya pembelian ulang dan kesetiaan pelanggan, serta terciptanya rekomendasi dari mulut ke mulut yang memberikan keuntungan bagi perusahaan. Pelanggan yang puas akan kembali dan terus menggunakan jasa atau produk yang membuat ia puas sedangkan pelanggan yang tidak puas atau kecewa akan memberikan respon yang lebih buruk dua kali lipat mengenai pengalaman buruknya (Mononimbar, 2013). Berdasarkan pernyataan tersebut dapat disimpulkan bahwa kepuasan pelanggan mempunyai peran yang penting yang akan menentukan bahwa pelanggan tersebut akan membeli kembali produk atau jasa yang kita tawarkan atau akan memberikan kesan buruk dibenak pelanggan dan akan menyebabkan pelanggan tersebut tidak akan membeli produk atau jasa yang dimiliki perusahaan.

\section{HIPOTESIS PENELITIAN}

\section{Pengaruh fokus pada pelanggan terhadap kepuasan pelanggan}

Fokus pelanggan merupakan hal yang sangat penting yang perlu dilakukan oleh perusahaan untuk lebih memberikan kesan baik kepada pelanggan dan menciptakan kepuasan pelanggan. Memberikan pelayanan yang intensif adalah cara yang perlu dilakukan agar pelanggan lebih mengetahui produk atau jasa yang dipasarkan sehingga akan menimbulkan rasa ingin membeli dan rasa puas dibenak pelanggan. Penelitian oleh Amin (2011), Mehra (2008), Arumugam (2015), Hsing Liu (2015) dan Jaafreh (2013) telah meneliti sebelumnya dan menemukan bahwa fokus pada pelanggan berpengaruh positif terhadap kepuasan pelanggan, sehingga semakin meningkat fokus pada pelanggan maka semakin tinggi kepuasan 
pelanggan. Berdasarkan hasil empiris pada penelitian diatas, hipotesis yang dapat diajukan dalam penelitia ini adalah,

$\mathrm{H}_{1}$ : Fokus pada pelanggan memiliki pengaruh positif dan signifikan terhadap kepuasan pelanggan.

\section{Pengaruh obsesi terhadap kualitas terhadap kepuasan pelanggan}

Kualitas produk atau jasa yang dihasikan baik maka akan memberikan kesan baik pula pada pelanggan. Mutu perusahaan harus ditingkatkan agar produk atau jasa yang ditawarkan memiliki kualitas yang baik dan bisa memenuhi harapan atau keinginan pelanggan (Wuryanti, 2013). Penelitian sebelumnya oleh Rahman (2011), dan Monomimbar (2013), Citraluki (2016) memberikan hasil bahwa obsesi terhadap kualitas tidak berpengaruh terhadap kepuasan pelanggan. Berdasarkan hasil empiris pada penelitian diatas, hipotesis yang dapat diajukan dalam penelitia ini adalah,

$\mathrm{H}_{2}$ : Obsesi terhadap kualitas memiliki pengaruh positif dan signifikan terhadap kepuasan pelanggan.

\section{Pengaruh kerjasama tim terhadap kepuasan pelanggan}

Kerjasama tim merupakan bentuk kerja secara berkelompok dan saling melengkapi dengan ketrampilan masing - masing serta berkomitmen untuk mencapai tujuan bersama yaitu untuk membuat pelanggan merasa puas. Penelitian yang dilakukan Zaman (2014), Mahami (2015), Amin (2011), Rahman (2011) dan Andriyanto (2011) telah meneliti sebelumnya dan menyatakan bahwa kerjasama 
Pebriani Efendi, Pengaruh Implementasi Total Quality Management ...

tim berpengaruh terhadap kepuasan pelanggan. Berdasarkan hasil empiris pada penelitian diatas, hipotesis yang dapat diajukan dalam penelitia ini adalah,

$\mathrm{H}_{3}$ : Kerjasama tim memiliki pengaruh positif dan signifikan terhadap kepuasan pelanggan.

\section{METODE PENELITIAN}

Berdasarkan tinjauan pustaka dan empiris, maka disusun sebuah kerangka konseptual sebagai berikut.

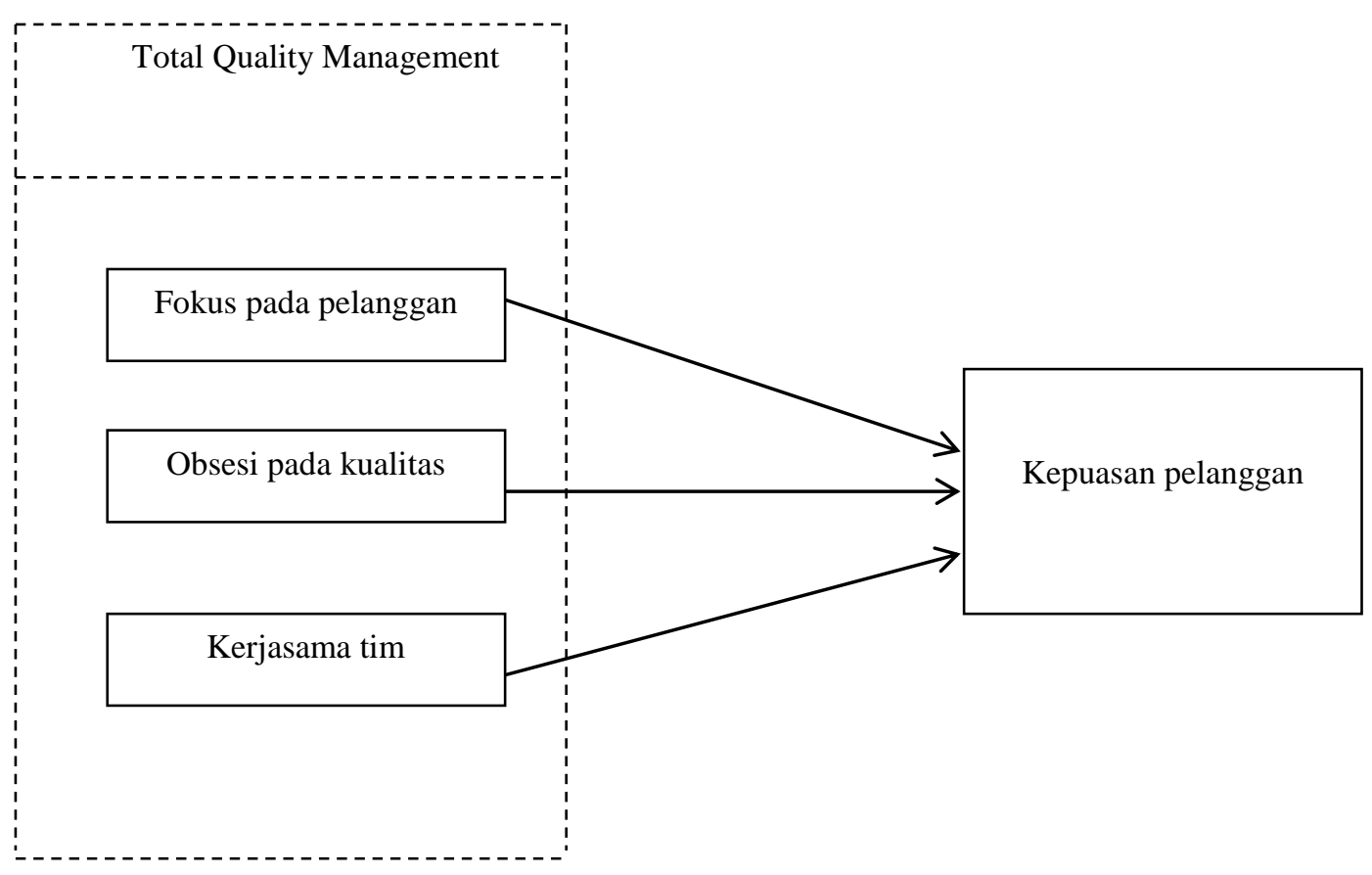

Gambar 1. Kerangka Konseptual Penelitian

Sumber : Hasil pemikiran peneliti,2017

Jenis penelitian ini dikategorikan sebagai penelitian asosiatif dengan metode analisis kuantitatif. Penelitian ini dilakukan di Barjaz yang berada di Jalan Diponegoro No 173, Denpasar. Obyek yang digunakan adalah kepuasan pelanggan Barjaz. Variabel yang terdapat dalam penelitian ini adalah variabel 
terikat dalam penelitian ini adalah kepuasan pelanggan perusahaan Barjaz yang disimbolkan dengan (Y). Variabel bebas dalam penelitian ini adalah Total Quality Management yang disimbolkan dengan (X) yang mempunyai tiga sub variabel fokus pada pelanggan, yang disimbolkan dengan (X1), Obsesi terhadap kualitas yang disimbolkan dengan (X2), dan kerjasama tim yang disimbolkan dengan (X3).

Definisi operasional dari variabel kepuasan pelanggan adalah tingkat perasaan pelanggan Barjaz setelah membandingkan kinerja pelayanan dan produk yang ia rasakan dibandingkan dengan harapannya, variabel kepuasan pelanggan memiliki lima indikator. Fokus pada pelanggan adalah sikap dan perilaku karyawan Barjaz dalam memberikan pelayanan yang baik kepada pelanggan, variabel fokus pada pelanggan memiliki empat indikator yaitu interaksi antara karyawan dan pelanggan pada saat pembayaran dikasir, pada saat melayani pelanggan, pada saat ada pertanyaan dari pelanggan dan pada saat memberikan informasi. Obsesi pada kualitas adalah upaya untuk meningkatkan mutu perusahaan salah satu usaha yang dapat dilakukan adalah dengan meningkatkan mutu perusahaan sehingga produk bisa memenuhi harapan atau keinginan pelanggan, variabel obsesi pada kualitas memiliki enam indikator yaitu mengenai tempat parkir, keramahan karyawan, kesabaran karyawan, aroma produk, packaging, dan higienis. Kerjasama tim adalah kerjasama karyawan Barjaz dengan keterampilan masing-masing yang saling melengkapi serta berkomitmen untuk mencapai tujuan bersama yaitu memuaskan pelanggan Barjaz, variabel kerjasama tim memiliki lima indikator. 
Tabel 1.

Indikator Penelitian

\begin{tabular}{|c|c|c|}
\hline Variabel & Indikator & Sumber \\
\hline $\begin{array}{l}\text { Fokus pada } \\
\text { Pelanggan }\end{array}$ & $\begin{array}{l}\text { Interaksi saat dikasir } \\
\text { Interaksi saat melayani pelangggan } \\
\text { Interaksi saat memberikan informasi } \\
\text { Interaksi saat ada pertanyaan dari pelanggan }\end{array}$ & Elvirawati (2013) \\
\hline $\begin{array}{l}\text { Obsesi pada } \\
\text { kualitas }\end{array}$ & $\begin{array}{l}\text { Tempat Parkir } \\
\text { Keramahan dan kesopanan karyawan Barjaz } \\
\text { Kesabaran karyawan Barjaz } \\
\text { Produk Barjaz memiliki aroma yang khas } \\
\text { Packaging yang menarik } \\
\text { Produk Barjaz terjamin higienis }\end{array}$ & Rahman (2011) \\
\hline Kerjasama tim & $\begin{array}{l}\text { Keseragaman jawaban } \\
\text { Kerjasama antar karyawan pada setiap divisi } \\
\text { Bertanggungjawab terhadap pekerjaannya masing- } \\
\text { masing } \\
\text { Terjadi kerjasama yang baik antar karyawan } \\
\text { Terjalin keakraban antar karyawan Barjaz }\end{array}$ & Mahami (2015) \\
\hline $\begin{array}{l}\text { Kepuasan } \\
\text { Pelanggan }\end{array}$ & $\begin{array}{l}\text { Perasaan puas setelah membeli produk Barjaz } \\
\text { Perasaan puas atas perhatian dan pelayanan yang } \\
\text { diberikan } \\
\text { Perasaan puas dengan harga dan kualitas yang } \\
\text { diberikan } \\
\text { Perasaan puas dengan variasi rasa } \\
\text { Perasaan puas terhadap cita rasa Teh Thailand di } \\
\text { Barjaz }\end{array}$ & Citraluki (2016) \\
\hline
\end{tabular}

Sumber : Penelitian - penelitian sebelumnya

Jumlah anggota sampel atau besarnya sampel ditetapkan dengan pertimbangan yang menyatakan, bahwa banyaknya sampel dapat ditentukan dengan jumlah indikator dalam model lima (5) hingga sepuluh (10) (Sugiyono, 2014:117) lalu dikalikan dengan jumah indikator. Penelitian ini menggunakan 170 sampel. Penelitian ini menggunakan teknik pengumpulan sampel non probability sampling dengan metode proposive sampling. Adapun kriteria responden dalam penelitian ini adalah responden yang sudah pernah berkunjung dan membeli produk di Barjaz minimal satu kali dalam kurun waktu satu bulan terakhir. 
Pertimbangan ini digunakan karena pelanggan yang telah mempunyai pengalaman membeli produk di perusahaan Barjaz akan dapat merasakan kualitas produk dan kualitas pelayanannya. Responden berpendidikan minimal SMA. Persyaratan pelanggan mengacu pada berbagai kelompok pelanggan dari sistem pendidikan (Sahney,2016). Kriteria ini dipilih agar responden memahami pernyataanpernyataan dalam kuesioner dan dapat menjawabnya dengan mandiri.

Data yang digunakan terdiri dari data kualitatif dan data kuantitatif. Data kualitatif berupa pendapat dari responden mengenai pernyaataan yang tertera dalam kuesioner dan sejarah berdirinya perusahaan seperti gambaran umum mengenai perusahaan Barjaz. Data kuantitatif berupa usia dari responden yang mengisi kuesioner. Sumber data yang digunakan terdiri data sumber primer dan sumber sekunder. Sumber primer diperoleh langsung dari hasil wawancara kepada Owner perusahaan Barjaz dan pengumpulan data menggunakan kuesioner kepada pelanggan Barjaz. Sumber sekunder dalam penelitian ini adalah data yang diperoleh melalui artikel perusahaan Barjaz di internet yang berupa jumlah pembeli, rasa teh Thailand Barjaz, dan gambaran perusahaan Barjaz.

Data dikumpulkan menggunakan instrumen penelitian berupa kuesioner. Kuesioner terdiri atas tiga bagian yaitu bagian pertama terdiri dari identitas peneliti, bagian kedua terdiri dari pertanyaan terbuka yaitu beberapa pertanyaan tentang identitas responden, dan bagian terakhir terdiri dari pernyataan tertutup yaitu sejumlah pernyataan yang meminta pendapat responden tentang penilaian terhadap sejumlah indikator dari tiap variable. Tiap indikator variabel penelitian 
diberi pilihan jawaban secara tertutup dengan menggunakan Skala Likert dengan keterangan dalam Tabel 2.

Tabel 2.

Alternatif Jawaban Responden

\begin{tabular}{lll}
\hline Simbol & Jawaban & Skor \\
\hline SS & Sangat Setuju & 5 \\
ST & Setuju & 4 \\
N & Netral & 3 \\
TS & Tidak Setuju & 2 \\
STS & Sangat Tidak Setuju & 1 \\
\hline Sumber $:$ Sugiyono (2014)
\end{tabular}

Kuesioner penelitian sebelum disebarkan kepada seluruh responden, terlebih dahulu diuji reliabitas dan validitasnya. Variabel dikatakan valid apabila koefisien korelasi lebih besar dari 0,30 yang merupakan nilai pembanding minimal untuk mendapatkan korelasi yang valid. Untuk mengukur reabilitas instrumen dalam penelitian ini adalah dengan Cronbach Alpha $(\alpha)$. Suatu variabel dikatakan reliabel jika memberikan nilai Cronbach Alpha $(\alpha)>0,60$ (Ghozali, 2013:47).

Teknik analisis data di bagi menjadi dua yaitu satistik deskriptif dan statistik inferensial. Menurut Ghozali (2013:19) Statistik deskriptif memberikan gambaran atau deskriptif suatu data yang dilihat dari nilai rata-rata (mean), standar deviasi, varian, maksimum, minimum, sum, range dan kurtosis.

Rata-rata skor jawaban responden dikelompokkan kedalama 5 kelas interval dengan formula sebagai berikut (Wirawan, $2002: 35$ )

Interval : $\quad$ (Nilai Tertinggi - nilai terendah)/(Jumlah kelas)
Interval :
$(5-1) / 5$
$=0,8$ 
Berdasarkan nilai interval tersebut, maka distribusi jawaban responden memiliki rentang penilaian seperti Tabel 3 sebagai berikut.

Tabel 3.

Rentang Penilaian Jawaban Responden

\begin{tabular}{lll}
\hline No & Rentang & Keterangan \\
\hline & & \\
1 & $1,00-1,79$ & Sangat Tidak Baik \\
2 & $1,80-2,59$ & Tidak Baik \\
3 & $2,60-3,39$ & Cukup Baik \\
4 & $3,40-4,19$ & Baik \\
5 & $4,20-5,00$ & Sangat Baik \\
\hline
\end{tabular}

Sumber : Wirawan (2002)

Statistik inferensial merupakan teknik statistik yang berfungsi untuk menganalisis suatu data sampel dan hasilnya diberlakukan untuk populasi. Statistik inferensial digunakan untuk menjawab hipotesis. Dalam penelitian ini, statistik inferensial yang digunakan adalah analisis regresi berganda. Model regresi linear berganda adalah sebagai berikut:

$$
\mathrm{Y}=\alpha+\beta 1 \mathrm{X} 1+\beta 2 \mathrm{X} 2+\beta 3 \mathrm{X} 3+\mathrm{e}
$$

Keterangan:

$$
\begin{array}{ll}
\mathrm{Y} & =\text { Kepuasan pelanggan } \\
\alpha & =\text { Kontanta } \\
\beta & =\text { Koefisien garis regresi } \\
\mathrm{X} 1 & =\text { Fokus pada pelanggan } \\
\mathrm{X} 2 & =\text { Obsesi pada kualitas } \\
\mathrm{X} 3 & =\text { Kerjasama tim } \\
\mathrm{e} & =\text { Error }
\end{array}
$$


Uji asumsi klasik adalah persyaratan statistik yang harus dipenuhi pada analisis regresi linear berganda yang berbasis ordinary least square (OLS). Agar model regregi berganda memenuhi syarat harus dilakukan uji asumsi klasik terlebih dahulu. Uji asumsi klasik yang sering digunakan yaitu uji multikolinearitas, uji heteroskedastisitas, uji normalitas, dan uji autokorelasi.

Uji normalitas bertujuan untuk menguji apakah dalam model regresi variabel bebas dan variabel terikat mempunyai distribusi normal atau tidak (Ghozali, 2013:160). Uji normalitas yang digunakan dalam penelitian ini adalah dengan melihat normal probability plot yang membandingkan distribusi kumulatif dari data sesungguhnya dengan distribusi kumulatif dari data normal. Model regresi yang baik apabila tidak ditemukannya korelasi antara variabel bebas. Jika model regresi dengan gejala multikorelasi digunakan, maka hasil prediksi yang dihasilakan akan menyimpang. Pengujian ini dapat digunakan dengan menggunakan nilai tolerance dan nilai Variance Inflation Faktor (VIF) dapat digunakan untuk melihat ada tidaknya korelasi antara variabel bebas. Jika nilai tolerance lebih dari 0,10 atau nilai VIF dibawah 10 maka ini menunjukkan tidak terjadinya multikolinieritas (Utama, 2014:105).

Menurut Ghozali (2013:139) uji heteroskedastisitas bertujuan untuk menguji dalam model regresi terjadi ketidaksamaan varian dari residual satu pengamatan ke pengamatan lain. Uji Autokorelasi yang sering digunakan adalah dengan uji Durbin Watson (DW) untuk mendeteksi uji autokorelasi. 


\section{HASIL DAN PEMBAHASAN}

Jumlah responden dalam penelitian ini adalah 170 responden. Profil responden yang diamati dalam penelitian ini adalah usia, jenis kelamin, tingkat pendidikan terakhir dan pekerjaan. Secara rinci profil responden disajikan dalam Tabel 4 sebagai berikut.

Tabel 4.

Profil Responden

\begin{tabular}{ccccc}
\hline No & Variabel & Klasifikasi & Jumlah (Orang) & Presentase (\%) \\
\hline \multirow{2}{*}{1.} & Usia (tahun) & $18-22$ & 138 & 81.1 \\
& Jumlah & $>22$ & 32 & 18.9 \\
2. & & $\mathbf{1 7 0}$ & $\mathbf{1 0 0}$ \\
& Jenis Kelamin & Laki - Laki & 41 & 24.1 \\
& Jumlah & Perempuan & 129 & 75.9 \\
3 & & $\mathbf{1 7 0}$ & $\mathbf{1 0 0}$ \\
& Pendidikan & SMA & 150 & 88.2 \\
& Terakhir & & 20 & 11.8 \\
& & Sarjana (S1) & $\mathbf{1 7 0}$ & 75.2 \\
& Jumlah & & 128 & 24.8 \\
& Pekerjaan & Mahasiswa & 42 & $\mathbf{1 0 0}$ \\
\hline
\end{tabular}

Sumber : Data primer yang diolah, 2017

Tabel 4 menunjukkan bahwa sebagian besar responden berada pada klasifikasi usia 18-22 tahun dengan persentase sebesar 81,1 persen sedangkan rentang usia diatas 22 tahun, sebesar 18,9 persen. Profil responden berdasarkan jenis kelamin didapat responden laki-laki berjumlah 24,1 persen sedangkan responden perempuan berjumlah 75,9 persen. Profil responden berdasarkan pendidikan terakhir SMA yaitu 88,2 persen dan Sarjana (S1) yaitu 11,8 persen. Profil responden berdasarkan pekerjaan didapat hasil sebesar 75,2 persen sebagai mahasiswa dan 24,8 persen sebagai orang yang telah bekerja. Jadi, dapat disimpulkan bahwa pelanggan Barjaz sebagian besar adalah mahasiswa.Kuesioner 
yang berisi pernyataan dari 170 responden di uji menggunakan uji validitas dan realibilitas. Hasil-hasil dari uji tersebut disajikan dalam tabel 5 sebagai berikut.

Tabel 5.

Hasil Uji Instrumen

\begin{tabular}{|c|c|c|c|c|}
\hline No & Variabel & Indikator & $\begin{array}{l}\text { Koefisien } \\
\text { Validitas }\end{array}$ & $\begin{array}{c}\text { Koefisien } \\
\text { Reliabilitas }\end{array}$ \\
\hline \multirow{4}{*}{1} & \multirow{4}{*}{$\begin{array}{l}\text { Fokus Pada } \\
\text { Pelanggan }\end{array}$} & Interaksi saat dikasir & 0,603 & \multirow{4}{*}{0,733} \\
\hline & & Interaksi saat melayani pelangggan & 0,600 & \\
\hline & & Interaksi saat memberikan informasi & 0,613 & \\
\hline & & Interaksi saat ada pertanyaan dari pelanggan & 0,496 & \\
\hline \multirow{6}{*}{2} & \multirow{6}{*}{$\begin{array}{l}\text { Obsesi terhadap } \\
\text { kualitas }\end{array}$} & Tempat Parkir & 0,481 & \multirow{6}{*}{0,726} \\
\hline & & Keramahan dan kesopanan karyawan Barjaz & 0,509 & \\
\hline & & Kesabaran karyawan Barjaz & 0,520 & \\
\hline & & Produk Barjaz memiliki aroma yang khas & 0,487 & \\
\hline & & Packaging yang menarik & 0,568 & \\
\hline & & Produk Barjaz terjamin higienis & 0,483 & \\
\hline \multirow{5}{*}{3} & \multirow{5}{*}{ Kerjasama Tim } & Keseragaman jawaban & 0,453 & \multirow{5}{*}{0,704} \\
\hline & & Kerjasama antar karyawan pada setiap divisi & 0,479 & \\
\hline & & $\begin{array}{l}\text { Bertanggungjawab terhadap pekerjaannya } \\
\text { masing-masing }\end{array}$ & 0,574 & \\
\hline & & Terjadi kerjasama yang baik antar karyawan & 0,600 & \\
\hline & & Terjalin keakraban antar karyawan Barjaz & 0,488 & \\
\hline \multirow{5}{*}{4} & \multirow{5}{*}{$\begin{array}{l}\text { Kepuasan } \\
\text { Pelanggan }\end{array}$} & $\begin{array}{l}\text { Perasaan puas setelah membeli produk } \\
\text { Barjaz }\end{array}$ & 0,537 & \multirow{5}{*}{0,703} \\
\hline & & $\begin{array}{l}\text { Perasaan puas atas perhatian dan pelayanan } \\
\text { yang diberikan }\end{array}$ & 0,567 & \\
\hline & & $\begin{array}{l}\text { Perasaan puas dengan harga dan kualitas } \\
\text { yang diberikan }\end{array}$ & 0,703 & \\
\hline & & Perasaan puas dengan variasi rasa & 0,714 & \\
\hline & & $\begin{array}{l}\text { Perasaan puas terhadap cita rasa Teh } \\
\text { Thailand di Barjaz }\end{array}$ & 0,642 & \\
\hline
\end{tabular}

Dari tabel 5 dapat diketahui bahwa semua indikator dalam kuesioner telah lolos uji validitas karena koefisien validitas lebih besar dari 0,3 sehingga semua instrumen yang digunakan valid. Hasil uji relialibiltas menunjukkan hasil koefisien reliabilitas lebih besar dari 0,6 sehingga layak dan memiliki konsistensi untuk digunakan.

Hasil dari deskripsi masing-masing variabel tersebut disajikan dalam Tabel 6 sebagai berikut. 
Tabel 6.

Penilaian Responden

\begin{tabular}{|c|c|c|c|c|c|c|c|}
\hline \multirow[t]{2}{*}{ Indikator } & \multicolumn{5}{|c|}{ Distribusi Jawaban } & \multirow{2}{*}{$\begin{array}{l}\text { Rata- } \\
\text { rata }\end{array}$} & \multirow{2}{*}{$\begin{array}{c}\text { Ketera } \\
\text { ngan }\end{array}$} \\
\hline & 1 & 2 & 3 & 4 & 5 & & \\
\hline Interaksi saat dikasir & 0 & 2.9 & 24.1 & 51.7 & 21.3 & 3.91 & Baik \\
\hline Interaksi saat melayani pelangggan & 0 & 1.5 & 17.95 & 53.5 & 27.05 & 4.06 & Baik \\
\hline Interaksi saat memberikan informasi & 0 & 0 & 12.4 & 54.1 & 33.5 & 4.21 & Baik \\
\hline $\begin{array}{l}\text { Interaksi saat ada pertanyaan dari } \\
\text { pelanggan }\end{array}$ & 0 & 1.7 & 41.2 & 45.3 & 11.8 & 3.67 & Baik \\
\hline \multicolumn{6}{|c|}{ Jumlah } & 3.96 & Baik \\
\hline Tempat parkir & 0 & 2.3 & 28.3 & 48.8 & 20 & 3.86 & Baik \\
\hline $\begin{array}{l}\text { Keramahan dan kesopanan karyawan } \\
\text { Barjaz }\end{array}$ & 0 & 1.8 & 30 & 50 & 18.2 & 3.84 & Baik \\
\hline Kesabaran karyawan Barjaz & 0 & 5.3 & 11.2 & 58.2 & 25.3 & 4.03 & Baik \\
\hline $\begin{array}{l}\text { Produk Barjaz memiliki aroma yang } \\
\text { khas }\end{array}$ & 0 & 1.2 & 27.6 & 48.8 & 22.4 & 3.92 & Baik \\
\hline Packaging yang menarik & 0 & 2.9 & 21.7 & 52.3 & 22.9 & 3.95 & Baik \\
\hline Higienis & 0 & 2.3 & 30.5 & 55.3 & 55.0 & 11.8 & Baik \\
\hline \multicolumn{6}{|c|}{ Jumlah } & 3.89 & Baik \\
\hline Keseragaman jawaban & 0 & 9.4 & 30 & 50.5 & 10 & 3.61 & baik \\
\hline $\begin{array}{l}\text { Kerjasama antar karyawan pada setiap } \\
\text { divisi }\end{array}$ & 0 & 1.8 & 14.7 & 57.6 & 25.8 & 4.07 & Baik \\
\hline Bertanggungjawab terhadap pekerjaan & 0 & 3.5 & 30.5 & 49.4 & 16.5 & 3.78 & Baik \\
\hline Terjadi kerjasama yang baik & 0 & 2.3 & 28.8 & 48.8 & 20 & 3.86 & Baik \\
\hline Terjalin keakraban & 0 & 1.8 & 30 & 50 & 18.2 & 3.84 & Baik \\
\hline \multicolumn{6}{|c|}{ Jumlah } & 3.83 & Baik \\
\hline Puas setelah membeli produk Barjaz & 0 & 0.5 & 25.8 & 57.1 & 16.4 & 3.89 & Puas \\
\hline Puas atas perhatian yang diberikan & 0 & 2.9 & 22.3 & 57.1 & 17.6 & 3.89 & Puas \\
\hline Puas dengan harga dan kualitas & 0 & 0 & 19.4 & 49.4 & 31.2 & 4.11 & Puas \\
\hline Puas dengan variasi rasa & 0 & 1.2 & 29.4 & 49.4 & 20 & 3.88 & Puas \\
\hline Puas terhadap cita rasa teh Thailand & 1.2 & 1.7 & 18.8 & 47.1 & 31.2 & 4.05 & Puas \\
\hline \multicolumn{6}{|c|}{ ah } & 3.96 & Puas \\
\hline
\end{tabular}

Sumber : Data yang diolah (2017)

Tabel 6 menunjukkan bahwa penilaian responden terhadap variabel bebas penelitian ini masuk kedalam kriteria baik. Dilakukan terlebih dahulu Uji asumsi klasik sebelum melakukan uji regresi berganda. Uji normalitas data digunakan untuk mengetahui apakah data yang diperoleh berdistribusi normal atau tidak. Penelitian ini dilakukan dengan pengujian normalitas dengan grafik P-P Plot untuk pengujian residual model regresi yang tampak pada gambar 2 berikut. 
Pebriani Efendi, Pengaruh Implementasi Total Quality Management ...

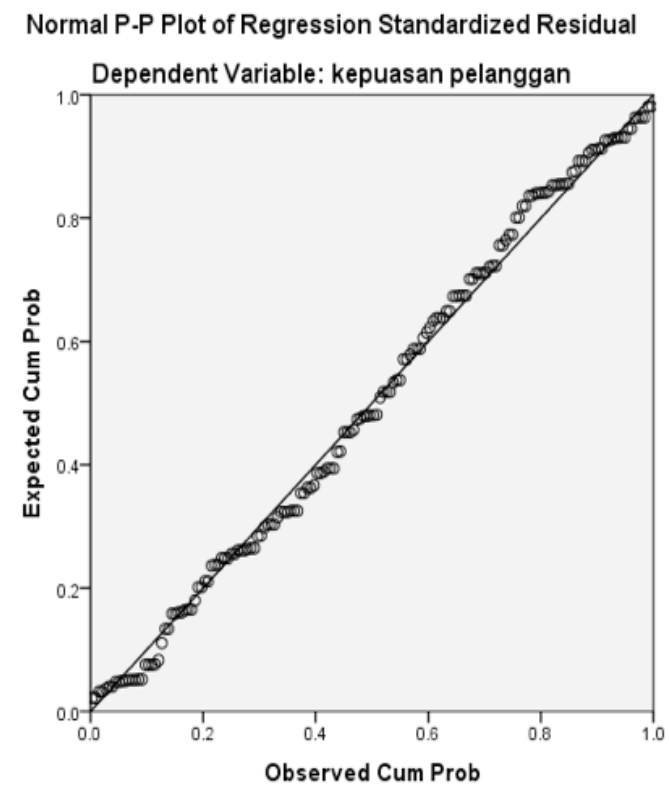

Gambar 2. Hasil Uji Normalitas

Sumber : Data diolah, 2017

Grafik normal probability plot menunjukkan bahwa data menyebar di sekitar garis diagonal dan mengikuti arah garis diagonal, maka model regresi memenuhi asumsi normalitas. Uji multikolinearitas bertujuan untuk menguji adanya korelasi antar variabel bebas dalam persamaan regresi. Adapun nilai VIF dan tolerance dapat dilihat pada Tabel 7 dibawah ini.

Tabel 7.

Hasil Uji Multikolinearitas

\begin{tabular}{llll}
\hline & \multicolumn{2}{c}{ Model } & \multicolumn{2}{c}{ Collonearity Statistics } \\
\cline { 3 - 3 } & & Tolerance & VIF \\
\hline $1 \quad$ (Constant) & & 1,089 \\
& Fokus pada Pelanggan & 0,918 & 1,536 \\
& Obsesi terhadap Kualitas & 0,651 & 1,593 \\
\hline & Kerjasama Tim & 0,628 & \\
\hline
\end{tabular}

Sumber : Data diolah, 2017 
Tabel 7 terlihat bahwa tidak ada variabel yang memiliki nilai VIF lebih besar dari 10 dan nilai tolerance yang lebih kecil dari 10 persen. Fokus pelanggan memiliki nilai tolerance 0,918 lebih besar dari 0,1 dan nilai VIF 1,089 lebih kecil dari 10. Obsesi pada kualitas memiliki nilai tolerance 0,651 lebih besar dari 0,1 dan nilai VIF 1,536 lebih kecil dari 10. Kerjasama tim memiliki nilai tolerance 0,628 lebih besar dari 0,1 dan nilai VIF 1,593 lebih kecil dari 10. Hal tersebut berarti bahwa tidak terdapat multikolinearitas antar variabel bebas dalam model regresi.

Tabel 8.

Hasil Uji Heteroskedastisitas

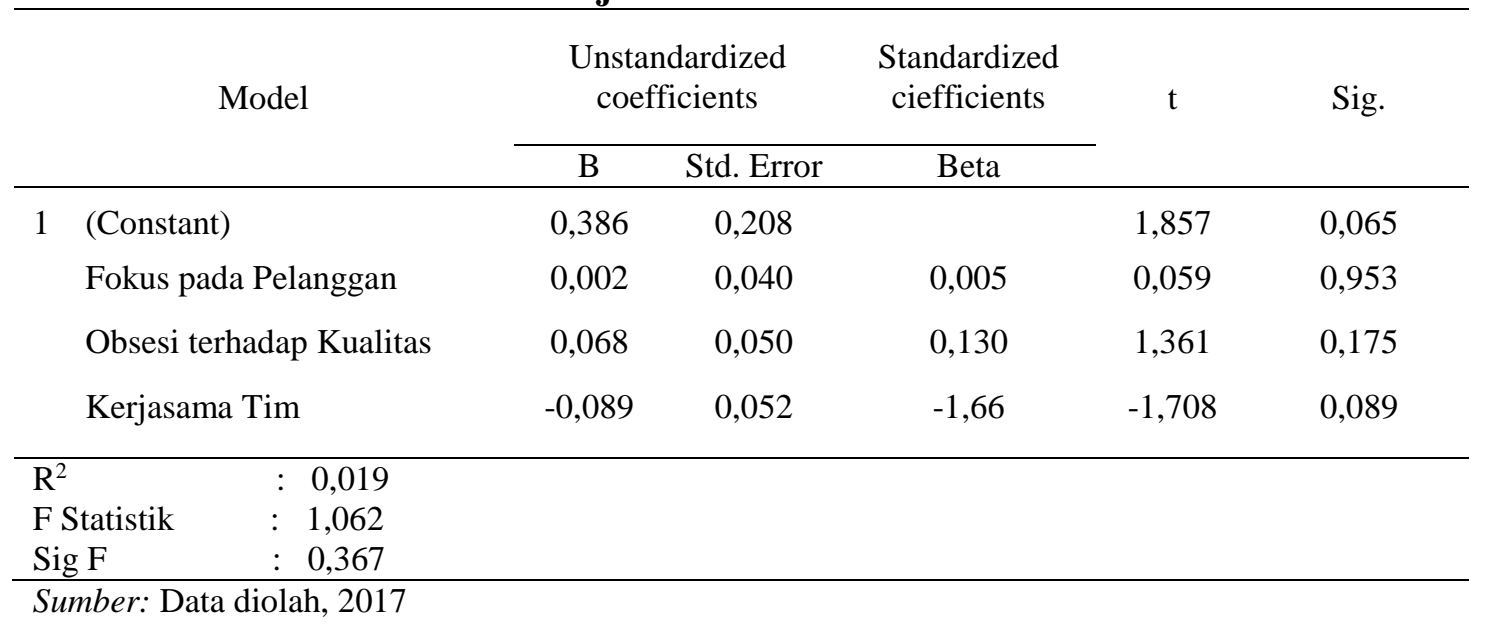

Masing-masing variabel memiliki nilai memiliki p value lebih besar dari 0,05. Model regresi tidak mengandung gejala heteroskedastisitas, sehingga layak untuk digunakan untuk memprediksi. Hasil uji autokorelasi dalam penelitian ini bisa dilihat dalam Tabel berikut:

Tabel 9. Hasil Uji Autokorelasi

\begin{tabular}{lccccc}
\hline Model & $\mathrm{R}$ & $\mathrm{R}$ Square & $\begin{array}{c}\text { Adjusted R } \\
\text { Square }\end{array}$ & $\begin{array}{c}\text { Std. Error of } \\
\text { the Estimate }\end{array}$ & $\begin{array}{c}\text { Durbin - } \\
\text { Watson }\end{array}$ \\
\hline 1 & 0,732 & 0,583 & 0,570 & 0,38885 & 1,821 \\
\hline Sumber: Data diolah, 2017 & \multicolumn{4}{l}{}
\end{tabular}


Hasil pengujian statistik menggunakan program SPSS menunjukkan nilai probabilitas sebesar 0,000 lebih kecil dari nilai taraf signifikansi 0,05 artinya $\mathrm{H} 0$ ditolak dan Ha diterima. Hal ini berarti bahwa secara simultan (bersama-sama) variabel fokus terhadap pelanggan, obsesi pada kualitas, dan kerjasama tim mempunyai pengaruh yang signifikan terhadap kepuasan pelanggan Barjaz. Variabel X1 menunjukkan nilai probabilitas sebesar 0,000 lebih kecil dari nilai taraf signifikansi 0,05 artinya H0 ditolak dan Ha diterima. Hal ini berarti bahwa secara parsial variabel fokus pada pelanggan berpengaruh positif signifikan terhadap kepuasan pelanggan Barjaz. Variabel X2 menunjukkan nilai probabilitas sebesar 0,031 lebih kecil dari nilai taraf signifikansi 0,05 artinya $\mathrm{H} 0$ ditolak dan Ha diterima. Hal ini berarti bahwa secara parsial variabel Obsesi pada Kualitas berpengaruh positif signifikan terhadap kepuasan pelanggan Barjaz. Variabel X3 menunjukkan nilai probabilitas sebesar 0,002 lebih kecil dari nilai taraf signifikansi 0,05 artinya $\mathrm{H} 0$ ditolak dan Ha diterima. Hal ini berarti bahwa secara parsial variabel Kerjasama Tim berpengaruh positif signifikan terhadap kepuasan pelanggan Barjaz.

Koefisien determinasi yang diperoleh sebesar 0,583. Hal ini berarti 58,3 persen kepuasan pelanggan dapat dijelaskan oleh variabel fokus pada pelanggan, obsesi pada kualitas, dan kerjasama tim, sedangkan sisanya yaitu 41,7 persen kepuasan pelanggan dipengaruhi oleh variabel-variabel lainnya yang tidak diteliti dalam penelitian ini. 


\section{Hasil pengujian hipotesis}

\section{1) Pengaruh fokus pada pelanggan terhadap kepuasan pelanggan}

Berdasarkan hasil yang diperoleh nilai koefisien Beta sebesar 0,286 dengan tingkat signifikansi sebesar 0,000 lebih kecil dari ,.05 yang berarti Ho ditolak dan Ha diterima. Hal tersebut berarti bahwa variabel fokus pada pelanggan(X1) berpengaruh positif signifikan terhadap kepuasan pelanggan. Jadi, setiap meningkatnya indikator fokus pada pelanggan maka akan meningkatkan kepuasan pelanggan, sebaliknya menurunnya indikatpr fokus pada pelanggan akan menyebabkan penurunan kepuasan pelanggan. Variabel fokus pada pelanggan merupakan variabel yang mempunyai nilai standardized coefficients lebih besar dari variabel lainnya yaitu sebesar 0,270 artinya bahwa variabel fokus pada pelanggan mempunyai pengaruh paling kuat terhadap kepuasan pelanggan.

Interaksi antara karyawan dengan pelanggan saat pembayaran dikasir, interaksi antara karyawan dengan pelanggan saat melayani pelanggan, interaksi antara karyawan dengan pelanggan saat memberikan informasi dan interaksi saat ada pertanyaan dari pelanggan, berpengaruh terhadap peningkatan kepuasan pelanggan. Indikator interaksi antara karyawan dengan pelanggan saat memberikan informasi merupakan indikator yang mempunyai nilai rata-rata yang paling besar diantara indikator fokus pada pelanggan yang lainnya.

Hasil penelitian ini sesuai dengan hasil penelitian sebelumnya yang dilakukan oleh Amin (2011), Mehra (2008), Arumugam (2015), Hsing Liu (2015) dan Jaafreh (2013), menyatakan bahwa fokus pada pelanggan (X1) berpengaruh positif terhadap kepuasan pelanggan. 


\section{2) Pengaruh obsesi terhadap kualitas terhadap kepuasan pelanggan}

Berdasarkan hasil yang diperoleh nilai koefisien Beta sebesar 0,199 dengan tingkat signifikansi sebesar 0,031 lebih kecil dari 0,05 yang berarti Ho ditolak dan Ha diterima. Hal tersebut berarti bahwa variabel obsesi pada kualitas berpengaruh positif signifikan terhadap kepuasan pelanggan. Jadi, peningkatan obsesi pada kualitas akan menyebabkan kenaikan kepuasan pelanggan, sebaliknya menurunnya obsesi pada kualitas akan menyebabkan penurunan kepuasan pelanggan. Variabel obsesi pada kualitas merupakan variabel yang mempunyai nilai standardized coefficients paling kecil dari variabel lainnya yaitu sebesar 0,177 artinya bahwa variabel obsesi pada kualitas mempunyai pengaruh paling lemah terhadap kepuasan pelanggan.

Tempat parkir yang luas, keramahan dan kesopanan karyawan, kesabaran karyawan, produk beraroma khas, packaging menarik, dan produk yang higienis berpengaruh terhadap peningkatan kepuasan pelanggan. Indikator kesabaran karyawan merupakan indikator yang mempunyai nilai rata-rata yang paling besar diantara indikator obsesi pada kualitas yang lainnya. Hasil penelitian ini sesuai dengan hasil penelitian sebelumnya yang dilakukan oleh Elvirawati (2013), Mahami (2015), Sukardi (2016) menyatakan bahwa obsesi pada kualitas berpengaruh positif terhadap kepuasan pelanggan.

\section{3) Pengaruh kerjasama tim terhadap kepuasan pelanggan}

Berdasarkan hasil yang diperoleh nilai koefisien Beta sebesar 0.293 dengan tingkat signifikansi sebesar 0.002 lebih kecil dari 0.05 yang berarti Ho ditolak dan Ha diterima. Hal tersebut berarti bahwa variabel kerjasama tim berpengaruh 
positif signifikan terhadap kepuasan pelanggan. Jadi, peningkatan kerjasama tim akan menyebabkan kenaikan kepuasan pelanggan, sebaliknya menurunnya kerjasama tim akan menyebabkan penurunan kepuasan pelanggan. Keseragaman jawaban yang diberikan, kerjasama antar karyawan dalam menyediakan perlengkapan, tanggung jawab masing-masing karyawan, kerjasama yang baik antar karyawan dan keakraban antar karyawan berpengaruh terhadap peningkatan kepuasan pelanggan. Variabel kerjasama tim merupakan variabel yang mempunyai nilai standardized coefficients terbesar kedua setelah variabel fokus pada pelanggan yaitu sebesar 0,256 artinya bahwa variabel kerjasama tim mempunyai pengaruh yang kuat terhadap kepuasan pelangga. Hasil penelitian ini sesuai dengan hasil penelitian sebelumnya yang dilakukan oleh Mahami (2015), Amin (2011), Rahman (2011) dan Andriyanto (2011) menyatakan bahwa kerjasama tim berpengaruh positif terhadap kepuasan pelanggan.

\section{SIMPULAN DAN SARAN}

Berdasarkan pembahasan hasil penelitian yang telah dilakukan, maka dapat diambil kesimpulan sebagai berikut: Fokus pada pelanggan, obsesi terhadap kualitas, dan kerjasama tim berpengaruh positif dan signifikan terhadap kepuasan pelanggan perusahaan Barjaz, artinya semakin meningkat fokus terhadap pelanggan, obsesi pada kualitas, dan kerjasama tim maka kepuasan pelanggan akan semakin meningkat.

Berdasarkan kesimpulan yang penulis kemukakan di atas, maka penulis dapat memberikan beberapa saran yang diharapkan dapat berguna bagi semua pihak. Saran-saran tersebut yaitu fokus terhadap pelanggan adalah faktor yang 
paling dominan terhadap kepuasan pelanggan, untuk itu pihak manajemen perusahaan Barjaz sebaiknya lebih memfokuskan untuk meningkatkan indikator indikator dalam variabel fokus pada pelanggan seperti memberi wewenang atau kebebasan kepada karyawan untuk berinteraksi secara langsung dengan pelanggan dan melakukan tindakan yang diperlukan untuk memuaskan pelanggan, misalnya dengan memberikan bantuan kepada pelanggan dan menyelesaikan keluhan pelanggan dengan cepat. Variabel obsesi pada kualitas masih didalam kategori baik, sebaiknya perusahaan Barjaz meningkatkan indikator yang ada agar meningkat menjadi kategori sangat baik. Variabel kerjasama tim juga memiliki hasil penilaian dalam kategori baik belum mencapai kategori sangat baik. Hal ini mendorong perusahaan Barjaz agar meningkatkan kemampuan kerja karyawan dengan cara memberi arahan dan pelatihan kepada karyawan untuk menguasai divisinya masing - masing.

\section{REFERENSI}

Amalina, RA Nur, Imroatul Khasanah. 2015. Analisis Pengaruh Persepsi Harga, Kualitas Layanan Dan Lokasi Terhadap Keputusan Pembelian (Studi pada Rocket Chicken Sukorejo Kendal). Diponegoro Journal Of Management, $4(2): 1-9$.

Amin, Muslim. 2016. Internet banking service quality and its implication on ecustomer satisfaction and e-customer loyalty. International Journal of Bank Marketing, 34(3):280-306.

Andre, Florentina dan Law Tjun Tjun. 2014. Pengaruh Total Quality Management (TQM) Terhadap Kualitas Pelayanan dan Kepuasan Konsumen di Jurusan Akuntansi Fakultas Ekonomi Salah Satu Universitas di Bandung . Jurnal Akuntansi,6 (1):47 - 83.

Angeline,Liu Chintya, Amna Hartiati, dan Dewa Ayu Anom Yuarini. 2014. Analisis Faktor Kualitas Produk Dan Jasa Pelayanan Terhadap Tingkat Kepuasan Konsumen Pia Sinar Abadi Bali. Skripsi. Fakultas Teknologi Pertanian Universitas udayana. 
Arikunto, Suharsimi., 2006, Metode Penelitian: Prosedur Penelitian Suatu Pendekatan Praktik, Rineka Cipta, Jakarta

Arumugam.V, Hiaw Wei Chang, Keng-Boon Ooi, dan Pei-Lee Teh. 2009. Selfassessment of TQM practices: a case analysis. The Total Quality Management Journal, 21(1):46-58.

Asiya, Syed Aamir Saeed Jafery, dkk. 2012. Improving Employees Performance Through Total Quality Management. International Journal of Economics and Management Sciences, 1(8):19-24.

Barros, Síria, Paulo Sampaio and Pedro Saraiva. 2014. Quality Management Principles And Practices Impact On The Companies' Quality Performance. Journal ICQ'14-Tokyo, Japan,1(5):1-12.

Citraluki, Jaeqline. 2016. Pengaruh Penerapan Total Quality Management (Tqm) Terhadap Kepuasan Pelanggan Pada Indomaret Sekecamatan Kartasura Tahun 2016 .Skripsi. Fakultas Ekonomi Universitas Muhammadiyah, Surakarta.

Djumahir, Surachman Djumilah Zain, dan Ramlawati. 2011. Implikasi Praktek Total Quality Management (TQM) terhadap Daya Saing, Kepuasan Konsumen, dan Kinerja Bisnis pada Perusahaan Manufaktur di Kota Makassar. Jurnal Aplikasi Manajemen, 9 (3):818-825.

Elvirawati. 2013. Pengaruh Penerapan Total Quality Management Terhadap Kepuasan Konsumen Pada Hotel Berbintang Di Daerah Istimewa Yogyakarta. Skripsi. Fakultas Ekonomi Universitas Atma Jaya Yogyakarta.

Ghozali, Imam. 2013. Aplikasi Analisis Multivariate dengan Program SPSS. Edisi Keempat, Penerbit Universitas Diponogoro.

Hardjosoedarmo, Soewarso. 2004. Total Quality Management. Yogyakarta : Penerbit Andi.

Heizer, Jay and Barry Render. 2009. Operations Management (Manajemen Operasi). Jakarta Salemba Empat.

Hsing Liu, Chih ,Sheng-Fang Chou, dkk. 2015. How "quality" determines customer satisfaction Evidence from the mystery shoppers' evaluation. The TQM Journal, 27 (5):576-590.

Hutomo, Tri Hartantyo, dan Ratih Hendayani. 2015. Analisis Implementasi Total Quality Management (TQM) Dan Pengaruhnya Terhadap Kepuasan Konsumen Dan Service Quality. Jurnal Manajemen Pemasaran, 4 (2):136- 
149.

Jaafreh, Ali Bakhit. 2013. The Effect of Quality Management Practices on Organizational Performance in Jordan:An Empirical Study. International Journal of Financial Research, 4 (2):167-193.

Joiner, Therese A. 2007. Total quality management and performance The role of organization support and co-worker support. International Journal of Quality \& Reliability Management, 24 (6):617-627.

Karani, Sharon R and Bichanga, Walter Okibo. 2012. Effects of Total Quality Management implementation on business performance in service institutions: A case of Kenya Wildlife Services. International Journal of Research Studies in Management, 1(1): 59-76.

Korankye, A.Addae. 2013. Total Quality Management (Tqm): A Source Of Competitive Advantage. A Comparative Study Of Manufacturing And Service Firms In Ghana. International Journal of Asian Social Science, 3(6):1293-1305.

Kotler, Philip. 2001. Manajemen Pemasaran : Analisis, Perencanaan, Implementasi, dan Kontrol. Jakarta : PT. Prehallindo

Kraim, H. 2011. The Influence Brand Loyalty on Cosmetics Buying Behavior of UAE Female Consumers. International Journal of Marketing Studies, 3(2): 123-133.

Lim, Dr Puay Cheng and Dr Nelson K H Tang. 2012. Total Quality Management in Practice: A Singapore Healthcare Study. International Journal of Applied Health Studies, 1(2): 1-7.

Mahami, Cahya. 2015. Pengaruh Penerapan Total Quality Management (Tqm) dan Kualitas Layanan Terhadap Kepuasan Pelanggan di Hotel Sala View Surakarta. Skripsi. Fakultas Ekonomi Universitas Muhammadiyah, Surakarta.

Malhotra, Naresh K. 2006. Riset Pemasaran Jilid II, Indeks, Jakarta.

Mehra, Satish and Sampath Ranganathan. 2008. Implementing total quality management with a focus on enhancing customer satisfaction. International Journal of Quality \& Reliability Management, 25 (9): 913-927

Mononimbar, Chrisye N. 2013. Total Quality Management (Tqm) Pengaruhnya Terhadap Kinerja Pelayanan Dan Kepuasan Konsumen Pada Pt. Taspen Manado. Jurnal EMBA, 1(3):1041-1048. 
Mosahab, Rahim. 2013. Examining the effects of contextual factors on TQM and performance through the lens of organizational theories: An empirical study. Journal of Operations Management ,2(5): 83-109.

Nasution, M.N, 2001. Manajemen Mutu Terpadu. Jakarta: Ghalia Indonesia.

Ngambi ,Marcel T., dan Ayankeng Godlove Nkemkiafu. 2015. The Impact of Total Quality Management on Firm's Organizational Performance. American Journal of Management, 15 (4): 69-85.

Noor, Mitha Fadilla. 2014. Pengaruh Brand Image Dan Brand Trust Terhadap Brand Loyalty King Thai Tea Bandung. Image. 3(2): 127-140.

Novrianto, Yusuf, Rudy Soenoko, Purnomo Budi Santoso. 2014. Analisis

Penerapan Total Quality Management (TQM) Industri Pertahanan Nasional. Jemis, 2 (1): 19-25.

Ooi, Keng Boon, Binshan Lin, Boon-In Tan, dan Alain Y ee-Loong Chong. 2011. Are TQM practices supporting customer satisfaction and service quality. Journal of Services Marketing,25(6): 410-419.

Prawirosentono, Suyadi. 2001. Manajemen Mutu Terpadu (Total Quality Manajement). Jakarta: Bumi Aksara.

Rahman, Fajri Ziha. 2011. Penerapan Total Quality Manajement Serta Pengaruhnya Terhadap Kinerja Pelayanan Islami dan Kepuasan Konsumen di Rumah Sakit Islam Kendal. Semarang. Skripsi. Institut Agama Islam Negeri Walisongo.

Sahney, Sangeeta. 2016. Use of multiple methodologies for developing a customer- oriented model of total quality management in higher education. International Journal of Educational Management,30 (3): 326-353.

Santoso, Singgih. 2012. Panduan Lengkap SPSS Versi 20. Jakarta: PT Elex Media Komputindo.

Siswanto, H B. 2006. Pengantar Manajemen. Jakarta: Bumi Aksa.

Sugiyono. 2014. Metode Penelitian Bisnis. Bandung: Alfabeta.

Suharyono, Inka Janita Sembiring dan Andriani Kusumawati. 2014. Pengaruh Kualitas Produk Dan Kualitas Pelayanan Terhadap Kepuasan Pelanggan Dalam Membentuk Loyalitas Pelanggan (Studi Pada Pelanggan Mcdonald's Mt.Haryono Malang). Jurnal Administrasi Bisnis (JAB), 15 (1): 1-10. 
Sukardi, Ria amalia. 2016. Pengaruh Penerapan Total Quality Management (Tqm) Terhadap Kepuasan Pelanggan Pada Department Store di Plaza Mulia Samarinda. Jurnal Administrasi Bisnis, 4 (3): 759-772.

Suryawan, Sophan. 2010. Pengaruh Total Quality Manajemen (Tqm) Dan Kualitas Pelayanan Terhadap Kepuasan Pelanggan Dihotel Martonegaran Sragen. Skripsi. Fakultas Ekonomi Jurusan Manajemen Universitas Muhammadiyah, Surakarta.

Tjiptono, Fandy. 2003. Total Quality Manajement. Yogyakarta: Andi Offset.

Tjiptono, Fandy. 2012. Service Manajemen, Mewujudkan Layanan Prima. Yogyakarta: CV Andi Offset

Utama, Made Suyana. 2014. Aplikasi Analisis Kuantitatif. Edisi Kedelapan. Denpasar

Wicaksono, Hendra Dwi. 2013. Pengaruh Penerapan Total Quality Management (Tqm) Terhadap Kepuasan Pelanggan Pada Karaoke Nav Daerah Kecamatan Jebres Surakarta Tahun 2013. Skripsi Sarjana Jurusan Pendidikan Ekonomi pada Fakultas Keguruan dan Ilmu Pendidikan Universitas Sebelas Maret, Surakarta.

Wirawan, Nata. 2002. Cara Mudah Memahami Statistik 2 (Statistik Inferensia) Untuk Ekonomi dan Bisnis. Edisi Kedua. Denpasar: Keramat Emas.

Wuryanti, Lestari. 2013. Tinjauan Manajemen Mutu Terpadu (Total Quality Management) Dalam Meningkatkan Kepuasan Pelanggan. Jurnal Riset Akuntansi dan Manjemen, 2(2), hal.98-104.

Zaman, Ali. 2014. Service Quality, Customer Satisfaction and Loyalty: A Test of Mediation. International Business Research, 3 (4): 223-257.

Zulian, Yamit. 2004. Manajemen Kualitas Produk dan Jasa. Yogyakarta: Ekonisia.

Sukmadinata, Nana Syaodih. 2009. Metode Penelitian Pendidikan: Remaja Roskakarya. 